UDK: 159.931/.932.072.42-057.874 Original scientific paper

\title{
DIFFERENCES IN ACHIEVEMENT ON TESTS OF PERCEPTUAL ABILITIES IN LOWER AND UPPER ELEMENTARY SCHOOL GRADE STUDENTS INVOLVED IN THE PROCESS OF DETERMINING THE PSYCHOPHYSICAL STATE
}

Vanja Marković, doctoral student

Faculty of Educational Sciences Juraj Dobrila University of Pula Republic ofCroatia vamarkov@unipu.hr 


\begin{abstract}
This paper investigates whether there are differences in the results achieved during the assessment of visual and auditory perceptual abilities in students $(N=166)$ of upper and lower elementary school grades who are involved in the process of determining the psychophysical condition. Adequate assessment is important not only because of the prediction of students' academic success, but also as a basis for the development of individualized curricula that will enable the selection of adequate forms and content of educational support for each student. The Acadia developmental ability test was used to assess students' perceptual abilities. In data processing, in addition to calculating frequencies and arithmetic means by groups, in order to determine the deviation of the observed frequencies from the expected frequencies, the $\chi^{2}$-test was used. The results indicate the existence of significant differences in student achievement on the subtests of visual and auditory memory and visual differentiation. It turned out that lower results in all three tests were achieved by lower elementary school grade students. The pedagogical implications of this study indicate the need for more intensive educational monitoring of students from the beginning of their education.
\end{abstract}

Key words: students with disabilities, assessment, Acadia test, perceptual abilities, age differences. 


\section{INTRODUCTION}

The concept of perception refers to the cognitive process that identifies, organizes, and translates sensory data into meaningful information (Dhingra et al., 2010). Perceptual development follows four basic models of change (Bee, 1989, as cited in Kiš-Glavaš et al., 1997): significant expansion of the field of interest, increased awareness of the meaning of perceptual information, perception of the essential in perceptual information and development of the ability to ignore the irrelevant. Although perception depends on the intactness of sensory organs, it also depends on the structure of the nervous system that participate in the interpretation of stimuli, maturation, and previous experiences of the individual (Igrić et al., 1992). Disorders in the development of perceptual abilities refer to difficulties in the field of visual, auditory, tactile and / or kinesthetic perception. Numerous studies have linked the existence of difficulties in the field of perception with learning difficulties, especially in the younger school age, primarily difficulties in auditory processing, difficulties in visual perception or attention disorders (Dhingra et al., 2010). Difficulties in the development of perceptual functions in students, without timely detection of these difficulties and adequate support that should result from that detection, will significantly complicate the adoption of expected outcomes. The successful participation of students in school activities will be influenced by the development of all these perceptual abilities. However, since most teaching in our schools takes place in such a way that the emphasis is on the visual and auditory perceptual area, the development of visual and auditory discrimination and visual and auditory memory will be of special importance. A comparison of memory and learning shows that in learning, intentional and systematic, a person receives information in a ratio of $83 \%$ visually and $11 \%$ by hearing (Andrilović, 2001, as cited in Dobrić, Mildner, 2007). However, when assessing students' learning capacity, their preferred learning style, and the contextual framework in which learning takes place should also be considered.

\section{Perceptual abilities}

Visual perception relies on sight, which plays a major role in the perception of the environment, so even in the cerebral cortex, the largest area is dedicated to the processing of visual information (compared to other senses). The basic visual perception of objects involves the integration of several basic features (Grieve, 2000): colour, depth, perception of figure and background, and constancy of form. Visual perception and visuomotor integration are very sensitive indicators 
of a child's development (Bushnell, Boudreau, 1993; Feder, Majnemer, 2007, s cited in Bezrukikh et al., 2009). Numerous visuoperceptual operations mature ontogenetically very early. By the time a child starts school, the system of his visual perception is already highly organized: memory and recognition of geometric shapes at that time reach their maturity, while letter recognition is still difficult to achieve since this skill requires the development of more complex mechanisms (Bezrukikh et al., 2009). Delays in the development of visual perception may underlie difficulties in developing the skills necessary for learning and school success. In a study conducted on students who showed failure in school for no apparent reason, Dhingra et al. (2010) found that as many as $27.5 \%$ of them showed obvious impairments of visual perception. The same research found that visual perception is highly correlated with student achievement in reading and math.

Auditory perception arises from sensory vibrations coming from the physical world. The auditory system senses sound vibrations within a certain frequency range. (Fay, 2012, as cited in Poeppel, Teng, 2021). It is a complex process that includes the detection, discrimination, identification, as well as recognition and understanding of sounds from the environment. Thanks to the processing of the auditory message in the brain, we can hear and understand speech messages and participate in communication. The development of auditory perception is directly related to the maturation of auditory neural pathways (Sharma et al., 2005). It begins as the development of auditory awareness and continues with the development of auditory differentiation, identification, and understanding of what is heard (Erber, Alencewicz, 1976, as cited in Cinar et al., 2018). Listening is the foundation for development and improvement of language and learning abilities. Along with speaking, reading, and writing, it makes up a set of abilities that are important for a child's development of communication and speech (Yalçinkaya et al., 2009). Therefore, the assessment and rehabilitation of auditory perception abilities in preschool and school age is of great importance. 


\section{OBJECTIVES, HYPOTHESIS, AND PURPOSE OF THE RESEARCH}

This paper investigates whether there are differences in the results achieved during the assessment of visual and auditory perceptual abilities in students of upper and lower elementary school grades who are involved in the process of determining the psychophysical condition. Indicators of learning difficulties can often be detected in the preschool or early school period, by assessing abilities and skills that are a prerequisite for the acquisition and application of academic knowledge and skills (Gligorović, 2013, as cited in Gligorović, Buha, 2015). Adequate assessment is important not only because of the prediction of students' academic success, but also as a basis for the development of individualized curricula that will enable the selection of adequate forms and content of educational support for each student.

Hypothesis $\mathrm{H}_{1}$ is set: there are differences in the achievements on the test of perceptual abilities between students of upper and lower elementary school grades who are involved in the process of determining the psychophysical state.

When it comes to the overall achievement on the Acadia test of developmental abilities, previous research has shown that there are significant age differences in the achieved results (Buha, Gligorović, 2015). Regarding differences in achievement in the areas of perceptual abilities, older children in previous studies showed significantly better results in auditory and visual discrimination and auditory memory, while age differences were not observed in visual memory (Buha, Gligorović, 2015). All previous research has documented the developmental progress of students with respect to age (Čolić, 2013; Gligorović, Vučinić, 2011; Gligorović, Vujanić, 2003).

\section{METHODS}

\section{Sample}

The research used archival data collected during the procedure of determining the developmental abilities of primary school students involved in the process of determining the psychophysical condition in the urban area of Pula. These are students whose developmental difficulties have been identified or are in the process of being identified. This area includes the cities of Pula and Vodnjan and the municipalities of Barban, Marčana, Ližnjan, Medulin and Svetvinčenat. The data refer to the period from 2010 to 2021 and include 166 students of both sexes, 
aged 6 to 12, who were referred for educational and rehabilitation assessment. The assessment included 109 lower elementary school grade students and 57 upper elementary school grade students.

\section{Instrument}

The Acadia test of developmental abilities (Atkinson et al., 1981) was used to assess students' perceptual abilities. The instrument was adapted and translated in Croatia in 1985 (Novosel, Mavrin Cavor, 1985). The reliability and validity of the test was assessed in our circumstances. The results proved to be appropriate - reliability $\mathrm{rtt}=0.89$, validity ro $=0.72$ (Novosel, 1983). The test covers the age range of 6 years and three months to 12 years and three months, divided into 11 age groups with an age difference of 6 months. Acadia consists of 13 subtests, and each subtest is intended to measure some aspects of the development of abilities required for successful participation in school activities (Novosel, 1978). Of these tests, four were used in the study to assess perceptual abilities. These are the subtests Auditory Discrimination, Auditory Memory, Visual Discrimination and Visual Memory (Đoković et al., 2014). Subtests are saturated with factors of skills needed for successful learning, which are not otherwise noticed. A maximum of 20 points can be scored on each of the subtests, and raw scores are converted to standardized points according to age, with an arithmetic mean of 50 and a standard deviation of 10. Addition of points gives a global standard score. A deviation of 1 SD below the average indicates a risk for reduced abilities that are a prerequisite for school success, while a deviation of $2 \mathrm{SD}$ represents reduced abilities that are a prerequisite for school success.

Visual discrimination refers to the ability to distinguish the shape of objects and letter surfaces, to distinguish position and direction and to observe sequences (Dobronić et alt., 2004), and is extremely important for the process of learning to read and write. Visual discrimination, among basic perceptual functions, stands out as the most important factor that contributes to the possibility of acquiring knowledge in the subject Nature and Society (Japundža-Milisavljević, ĐurićZdravković, 2010). With the Acadia developmental ability test, we examine visual discrimination by presenting four similar figures or words, and the student should choose one that matches the template shown. The subtest consists of 20 tasks.

Visual memory is defined as the retention and processing of visual information when it is no longer available in the sensory system (Campana, 2010, as cited in Tomić, 2017). Of particular importance for school success is the level of visual working memory, which refers to the processes of short-term retention of visual information with the aim of currently performing tasks (Luck, Vogel, 2013). The 
capacity of visual working memory is very limited, but information can be stored in it for a few seconds (Švegar, Domijan, 2007). It has been shown that students' achievements on visual memory tests positively correlate with success in numerous subjects (Glumbić et al., 2013). The visual memory subtest consists of 10 tasks that test short-term visual memory. The examiner shows the student a picture for one second, and the student should then either draw a picture that matches the template or choose the correct one from four similar pictures.

Auditory differentiation is a measure of the ability to receive and differentiate between auditory stimuli, as the result of the integration of experiences and the functioning of an individual's central nervous system (Schmidt, 1999). It allows the child to properly store the mental representation of the voice, which is a prerequisite for proper pronunciation (Blaži, 2011, as cited in Filić et al., 2017). Research shows that good auditory discrimination, through regular pronunciation skills, affects the development of phonemic awareness, and thus the initial reading and writing (Boets et al., 2011, as cited in Filić et al., 2017). An interesting finding emerged from the research conducted by Majda Schmidt in 1999. She applyed the Acadia test on students of typical development, students with disabilities integrated into the regular school and students with disabilities in schools that implement special education programmes. The research showed that students with disabilities in schools that implement special programmes achieve the same or better results than students of typical development in the field of auditory discrimination, which the author attributes to intensive practice of this type of task in special schools. In the Acadia test auditory discrimination is examined in such a way that the examiner reads to the student pairs of words and logatoms that sound similar. The student's task is to determine which of the word pairs are the same and which are different. The subtest consists of a total of 20 tasks.

Auditory memory serves to store information about sound, including acoustic features and information about sound categories and the so-called higher sound structure (Marković, 2020). In the relationship between visual and auditory memory, Gloede and Gregg (2019) note that auditory memory is consistently worse than visual memory, but is more resistant to information loss, and that information decays at a slower rate. We examine auditory memory with the Acadia test by verbally presenting the student with strings of numbers or strings of words that he needs to remember and write down or reproduce verbally in a short term. The subtest consists of a total of 15 tasks. 


\section{Data processing methods}

In data processing, in addition to calculating frequencies and arithmetic means by groups, to determine the deviation of the observed frequencies from the expected frequencies, the $\chi 2$-test was used, which is an integral part of the SPSS program 24.0 Standard Campus Edition (SPSS ID: 729357 20.05.2016.).

\section{RESULTS AND DISCUSSION}

Graph 1 shows the arithmetic means of the results on individual subtests in lower and upper elementary school grade students. We were interested in whether there was a difference in deviations from the average for chronological age between two groups of students. The first group consists of first- to fourth-grade students (lower elementary school grades) and the second of fifth- to sixth-garde students (upper elementary school grades). There are no students attending the seventh and eighth grades because they are too old for the application of the Acadia test of developmental abilities. To make the analysis clearer, we divided the results according to whether students show a deviation from the average with respect to chronological age for one or two standard deviations or whether the results achieved are consistent with the average for their chronological age.

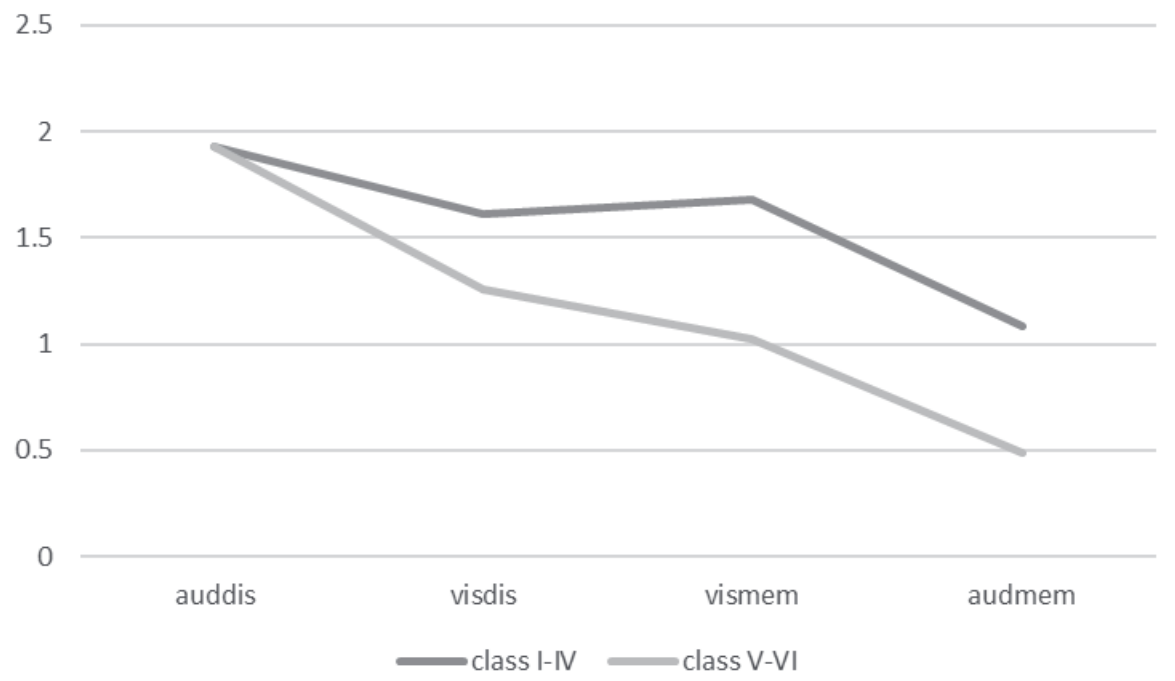

Graph 1. Arithmetic means of the results

It is generally observed that students in grades I-IV (lower grades) show less deviations than expected with respect to age in terms of below average. The largest 
deviation in terms of below-average for the age is visible in students in grades $\mathrm{V}$ and VI (upper grades) in the subtest Auditory Memory $(\mathrm{M}=0.49)$. The best result was achieved equally in upper and lower grade students in the Auditory Discrimination subtest $(\mathrm{M}=1.93)$.

Table 1. Relative and absolute frequencies and values of $\chi 2$ - test

\begin{tabular}{|c|c|c|c|c|c|c|}
\hline Subtest & grades & $\begin{array}{l}2 \text { and more } \\
\text { SD below } \\
\text { average }\end{array}$ & $\begin{array}{c}1 \mathrm{SD} \\
\text { below } \\
\text { average }\end{array}$ & average & $\chi^{2}$ & $\mathbf{p}$ \\
\hline \multirow{2}{*}{ Auditory Discrimination } & LG & $1.8 \%$ & $3.7 \%$ & $94.5 \%$ & \multirow{2}{*}{.004} & \multirow{2}{*}{.998} \\
\hline & UG & $1.8 \%$ & $3.5 \%$ & $94.7 \%$ & & \\
\hline \multirow{2}{*}{ Visual Discrimination } & LG & $13.8 \%$ & $11.9 \%$ & $74.3 \%$ & \multirow{2}{*}{6.957} & \multirow{2}{*}{$.031^{\star}$} \\
\hline & UG & $29.8 \%$ & $14 \%$ & $56.1 \%$ & & \\
\hline \multirow{2}{*}{ Visual Memory } & LG & $10.1 \%$ & $11.9 \%$ & $78 \%$ & \multirow{2}{*}{25.514} & \multirow{2}{*}{$.000^{*}$} \\
\hline & UG & $38.6 \%$ & $21.1 \%$ & $40.4 \%$ & & \\
\hline \multirow{2}{*}{ Auditory Memory } & LG & $31.2 \%$ & $29.4 \%$ & $39.4 \%$ & \multirow{2}{*}{23.229} & \multirow{2}{*}{$.000^{\star}$} \\
\hline & UG & $70.2 \%$ & $10.5 \%$ & $19.3 \%$ & & \\
\hline
\end{tabular}

$d f=2$

For three of the four subtests (Table 1), the deviations of the observed frequencies from the theoretical or expected frequencies can be considered significant since their values of the $\chi 2$ test are higher than the corresponding limit values at the appropriate degree of freedom.

The analysis of the Visual Discrimination subtest shows that lower grade students achieve better results than upper grade students. Upper grade students showed deviations in this category of both 2 standard deviations below the average, and 1 standard deviation below the average. Difficulties in visual discrimination relate to the mental representation of an object, which can affect students' ability to consistently recognize objects, letters, numbers, symbols, words, or images. Difficulties in this area will be manifested especially in reading, writing and mathematical skills. The Visual Memory subtest also shows the existence of 
statistically significant differences among lower and upper grade students, again in a way that lower grade students show significantly better results. As many as $38.6 \%$ of upper grade students showed a deviation of 2 standard deviations below the average in this area compared to $10.1 \%$ of lower grade students. In the category of students who show achievements that are 1 standard deviation below the average there is $21.1 \%$ of upper grade students and $11.9 \%$ of lower grade students. Gathercole and Baddley (1993, as cited in Amundsen et al., 2014) found that visual memory capacity increases with age, due to a more efficient application of memory strategies, better understanding of concepts, and greater repertoire of experiences to which information can be linked. Lower grade students need more time and more effort to memorize abstract symbols, primarily because of the connection between short-term memory ability and the degree to which children can assign some meaning to an object. However, this research showed that older students with developmental disabilities from our sample scored worse on the visual memory test than younger students. Visual memory depends not only on the students' age, but also on their cognitive abilities, working memory, attention capacity and the ability to use constructive strategies in specific learning situations.

\section{CONCLUSION}

Following the results, hypothesis $\mathrm{H}_{1}$, which assumes that there are differences in achievement on the test of perceptual abilities between students of upper and lower elementary school grades involved in the process of determining psychophysical condition, can be accepted, since the differences were statistically significant in three of the four examined subtests. However, even though numerous studies show that perceptual abilities mature and develop with the age of the child, in this study, lower grade students showed better results on the tests of visual discrimination and auditory and visual memory than upper grade students. A potential cause of this may be the fact that students who were detected too late as at risk for this type of difficulty were not included in rehabilitation programmes and procedures in a timely manner. Unfortunately, the educational perspective in the Republic of Croatia has not yet fully recognized the importance of early detection of developmental difficulties as well as the applicational value of multimodality and individualization of procedures. Also, in our practice, perceptual abilities are often seen as fixed capacities, although it is generally known that they can be developed through adequate rehabilitation procedures, professional and programme support and by teaching students constructive strategies. Therefore, the pedagogical implications of this study indicate the need for more intensive 
educational monitoring of students from the beginning of their education. For students who show deviations from the expected results according to age, it is necessary to provide a child focused educational support, which will equate their opportunity to achieve school success with the opportunities of typical pupils. 


\section{REFERENCES}

1. Amundsen, M., Garmannslund, P. E., Stokke, H. (2014). Visual working memory - gender and age differences. European Journal of Educational Sciences, 1 (3), 1-17.

2. Bezrukikh, M. M., Morozova, L. V., Terebova, N. N. (2009). Visual perception as an integrated characteristic of the psychophysiological development of six- to eight-year-old children. Human Physiology 35, 248-251.

3. Buha, N., Gligorović, M. (2015). Odnos postignuća na Akadija testu razvojnih sposobnosti i inteligencije kod dece mlađeg školskog uzrasta. Specijalna edukacija i rehabilitacija, 14 (3), 265284.

4. Cinar, M., Polat, Z., Yilar, S., Cetin Kara, H., Atas, A. (2018). Evaluation of Auditory Perception Abilities in Turkish Children with normal hearing. In 34th World Congress of Audiology. Cape Town.

5. Čolić, G. (2013). Dinamika razvoja leksikona kod dece mlađeg školskog uzrasta. Specijalna edukacija i rehabilitacija, 12 (4), 441-453.

6. Dhingra, R., Manhas, S., Kohli, N. (2010). Relationship of Perceptual Abilities with Academic Performance of Children. Journal of Social Sciences, 23 (2), 143-147.

7. Dobrić, A., Mildner, V. (2007). Pamtimo li bolje okom ili uhom?. Govor, 24 (1), 31-40.

8. Dobronić, A., Fulgosi Masnjak, R., Stančić, Z., Ivančić, Đ. (2004). Neke metrijske karakteristike instrumenta "Zadaci za procjenu govorne, slušne i vidne spremnosti za čitanje i pisanje”. Hrvatska revija za rehabilitacijska istraživanja, 40 (2), 237-249.

9. Đoković, S., Gligorović, M., Ostojić, S., Dimić, N., Radić-Šestić, M., Slavnić, S. (2014). Can mild bilateral sensorineural hearing loss affect developmental abilities in younger school-age children? Journal of Deaf Studies and Deaf Education, 19 (4), 484-495.

10. Filić, M., Kolundžić, Z., Vidović, I. (2017). Jezične i govorne sposobnosti, predvještine čitanja, pisanja i matematike školskih obveznika 2017./2018. u Požeško-slavonskoj županiji. Logopedija, 7 (2), 49-55.

11. Gligorović, M., Buha, N. (2015). Razvojne sposobnosti i postignuća u oblastima srpskog jezika i matematike. Specijalna edukacija i rehabilitacija, 14 (3), 319-344.

12. Gligorović, M., Vučinić, V. (2011). Kvalitet crteža dece mlađeg školskog uzrasta. Specijala edukacija i rehabilitacija, 10 (2), 193-205.

13. Gligorović, M., Vujanić, E. (2003). Organizovanost vizuelnih sposobnosti kod dece mlađeg školskog uzrasta. Istraživanja u defektologiji, 3, 121-133.

14. Gloede, M., Gregg, M. (2019) The fidelity of visual and auditory memory, Psychonomic bulletin and review, 26, 1325-1332.

15. Glumbić, N. P., Kaljača, S., Brojčin, B. (2003). Kratkoročno vizuelno pamćenje kod dece mlađeg školskog uzrasta. Istraživanja u defektologiji, 3, 141-154.

16. Grieve, J. (2000). Neuropsychology for occupational therapists: Assessment of perception and cognition (2nd ed.). Oxford: Blackwell Science.

17. Igrić, Lj., Levandovski, D., Kiš-Glavaš, L. (1992). Perceptivne sposobnosti djece bez teškoća u razvoju i djece usporena kognitivnog razvoja (PMZ-test). Defektologija, 28 (1-2), 21-37. 
18. Japundža-Milisavljević, M., Đurić-Zdravković, A. (2010). Neki činioci postignuća u oblasti prirode i društva kod dece sa lakom intelektualnom ometenošću. Inovacije u nastavi, 23 (3), 1622.

19. Kiš-Glavaš, L., Teodorović, B., Levandovski, D. (1997). Program bazične perceptivno-motorne stimulacije. Zagreb: Fakultet za defektologiju Sveučilišta u Zagrebu.

20. Luck, S. J., Vogel, E. K. (2013). Visual working memory capacity: From psychophysics and neurobiology to individual differences. Trends in Cognitive Sciences, 17 (8), 391-400.

21. Marković, F. (2020). Važnost slušnog pamćenja u govoru (Diplomski rad). Retrieved from: https:// urn.nsk.hr/urn:nbn:hr:131:948231 (7/5/2021)

22. Mishra, S. K., Saxena, U. (2020). Basic Measures of Auditory Perception in Children: No Evidence for Mediation by Auditory Working Memory Capacity. Frontiers in Human Neuroscience, 14 (59), $1-7$.

23. Novosel, M., Nikolić, B. (1989). Teškoće u razvoju, školski uspjeh, socio-ekonomski status te uspjeh u testu ACADIA u relaciji spola učenika osnovne škole. Defektologija, 25 (1), 59-72.

24. Poeppel, D., Teng, X. (2021). Audition. In B. Fritzsch (Ed.) The Senses: A Comprehensive Reference (2nd ed., pp. 63-76). Amsterdam, Elsevier.

25. Schmidt, M. (1999). Učenici s teškoćama u učenju i njihova socijalna integracija. Hrvatska revija za rehabilitacijska istraživanja, 35 (1), 1-10.

26. Sharma, A., Dorman, M. F., Kral, A. (2005). The influence of a sensitive period on central auditory development in children with bilateral and unilateral cochlear implants. Hearing Research, 203, 134-143.

27. Švegar, D., Domijan, D. (2007). Efekt serijalne pozicije u vidnomu radnom pamćenju. Psihologijske teme, 16 (1), 81-98.

28. Tomić, I. (2017). Vidno radno pamćenje. Psihologijske teme, 26 (3), 601-625.

29. Yalçınkaya, F., Muluk, N. B., Şahin, S. (2009). Effects of listening ability on speaking, writing and reading skills of children who were suspected of auditory processing difficulty. International journal of pediatric otorhinolaryngology, 73 (8), 1137-1142. 


\section{RAZLIKE U POSTIGNUĆU NA TESTOVIMA PERCEPTUALNIH SPOSOBNOSTI U UČENIKA NIŽIH I VIŠIH RAZREDA OSNOVNIH ŠKOLA UKLJUČENIH U PROGES UTVRĐIVANJA PSIHOFIZIČKOGA STANJA}

\section{SAŽETAK}

U ovome se radu istražuje postoje li razlike u rezultatima postignutim tijekom procjene vidnih $i$ slušnih perceptivnih sposobnosti kod učenika $(N=166)$ viših i nižih razreda osnovne škole, koji su uključeni u postupak utvrdivanja psihofizičkoga stanja. Adekvatna procjena nije značajna samo zbog predikcije akademskoga uspjeha učenika već i kao osnova za izradu individualiziranih kurikuluma koji će omogućiti odabir adekvatnih oblika i sadržaja odgojno-obrazovne podrške za svakoga učenika. Za procjenu perceptivnih sposobnosti učenika korišten je Acadia test razvojnih sposobnosti. U obradi podataka, uz izračunavanje frekvencija i aritmetičkih sredina po skupinama, radi utvrdivanja odstupanja opaženih frekvencije od očekivanih frekvencija, upotrjebljen je X2-test. Rezultati ukazuju na postojanje značajnih razlika u postignućima učenika na subtestovima vidnoga i slušnoga pamćenja $i$ vidnoga razlikovanja. Pokazalo se da bolje rezultate na svim trima testovima ostvaruju učenici nižih razreda. Pedagoške implikacije ovoga istraživanja ukazuju na potrebu za intenzivnijim edukacijskim praćenjem učenika od samoga početka njihova školovanja.

Ključne riječi: učenici s teškoćama, procjena, Acadia test, perceptivne sposobnosti, dobne razlike. 